\title{
ANTIOXIDANT ACTIVITY AND CARDIOPROTECTIVE ACTIVITY OF BANGUN-BANGUN LEAVES (PLECTRANTHUS AMBOINICUS LOUR.) ETHANOLIC EXTRACT
}

\author{
MODESTA HARMONI TARIGAN ${ }^{1}$, URIP HARAHAP ${ }^{1}$, AMINAH DALIMUNTHE ${ }^{1}$, NERDY NERDY ${ }^{2 *}$ \\ ${ }^{1}$ Department of Pharmaceutical Pharmacology, Faculty of Pharmacy, Universitas Sumatera Utara, Medan, Sumatera Utara, Indonesia \\ 20155. 'Department of Pharmaceutical Chemistry, Faculty of Pharmacy, Universitas Sumatera Utara, Medan, Sumatera Utara, \\ Indonesia 20155. Email: nerdy190690@gmail.com \\ Received: 24 April 2018, Revised and Accepted: 14 May 2018
}

ABSTRACT

Objectives: The objectives of this study were to determine the antioxidant activity and cardioprotective activity of bangun-bangun leaves ethanolic extract.

Methods: Bangun-bangun leaves ethanolic extract was obtained by maceration process. The antioxidant activity test was performed by 2,2'-azinobis(3-ethylbenzothiazoline-6-sulfonic acid) free radical scavenging method with various concentrations of extract. The absorbance was measured by visible spectrophotometric method and calculated the inhibitory concentration $\left(\mathrm{IC}_{50}\right)$ value for antioxidant activity analysis. Cardioprotective activity test was performed by measuring the cardiac troponin T (cTnT) level, creatine kinase-muscle/brain (CK-MB) level, and histology of the heart tissue. Animals induced with doxorubicin at the $8^{\text {th }}$ day and the $9^{\text {th }}$ day, bangun-bangun leaves ethanolic extract was administered from the $1^{\text {st }}$ day to the $9^{\text {th }}$ day with various doses of extract.

Results: Bangun-bangun leaves ethanolic extract had $\mathrm{IC}_{50}$ value of $57.79 \mu \mathrm{g} / \mathrm{mL}$. Difference dose of bangun-bangun leaves ethanolic extract shows difference cardioprotective activity. Bangun-bangun leaves ethanolic extract at dose $300 \mathrm{mg} / \mathrm{kg}$ bw did not differ significantly to the positive control group and normal group. The higher the dose of an extract the greater the decrease in cTnT and CK-MB levels and increase protection against heart damage.

Conclusion: Bangun-bangun leaves ethanolic extract had strong antioxidant and had cardioprotective activity.

Keywords: Antioxidant, Cardioprotective, Bangun-bangun leaves, Ethanolic extract, Doxorubicin.

(C) 2018 The Authors. Published by Innovare Academic Sciences Pvt Ltd. This is an open access article under the CC BY license (http://creativecommons. org/licenses/by/4. 0/) DOI: http://dx.doi.org/10.22159/ajpcr.2018.v11i9.26907

\section{INTRODUCTION}

Doxorubicin is an anthracycline antibiotic chemotherapeutic agent widely used as an anticancer with cardiotoxic side effects. Heart tissue has a very active metabolic ability but has a low source of antioxidants when compared with other organs. The use of doxorubicin is reported to the risk of side effects on heart tissue and suppresses the immune system [1].

Indonesia is a country rich in natural materials. These assets include plants, animals, and minerals. Many types of plants have been utilized by the community for healing, disease prevention, increased endurance, and refreshment of the body. Society is increasingly aware of the importance of back to nature by utilizing natural medicines because it is relatively safer than chemical drugs [2].

Bangun-bangun leaves contain saponins, flavonoids, polyphenols, essential oils, beta-carotene, niacin, carvacrol, calcium, fatty acids, oxalic acid, and fiber. Phytochemical studies reveal there are several types of flavonoids such as quercetin, luteolin, apigenin, saligenin, and genkwanin. Quercetin significantly facilitates cell survival by inhibiting cell apoptosis and maintaining cell morphology by inducing rearrangement of cytoskeletal proteins. By combining quercetin with doxorubicin, it will reduce cardiotoxicity in cancer chemotherapy [3]. The objective of this research was to determine the antioxidant activity and cardioprotective activity of buildup leaves ethanolic extract.

\section{METHODS}

This study is an experimental study to determine the antioxidant activity and cardioprotective activity of bangun-bangun leaves extract with various concentrations and various doses.
Tools

The tools used in this research were laboratory glassware, aluminum foil, desiccator (Iwaki), oven (Fisher), blender (National), rotary evaporator (Heidolph), vortex (Thermo), test tube (Iwaki), Beckman coulter (Beckman), link Dako epitope retrieval (Dako), tissue processor (Leica), paraffinausgieb station (Leica), spectrophotometer (Shimadzu), Cobas, and analytical balance (Boeco).

\section{Materials}

The materials used in this research were wax, doxorubicin, quercetin, sodium carboxymethyl cellulose, ketamine, Histoplast paraffin, creatine kinase-muscle/brain (CK-MB) reagent, cardiac troponin $\mathrm{T}$ (cTnT) reagent, toluene (Merck), distilled water (Brataco), hematoxylin-eosin (Merck), alcohol (Merck), methanol (Merck), and 2,2'-azino-bis(3ethylbenzothiazoline-6-sulfonic acid) (Sigma-Aldrich).

Preparation of bangun-bangun leaves ethanolic extract

About $500 \mathrm{~g}$ of dried and powdered bangun-bangun leaves was put into the vessel, added $3.75 \mathrm{~L}$ of ethanol, allowed for 5 days, filtered, squeezed the pulp, and washed with ethanol, to obtain $5 \mathrm{~L}$ of macerate. The extract was concentrated with a rotary evaporator and dried with a freeze dryer [4].

\section{Phytochemical screening of build leaves ethanolic extract}

Phytochemical screening of wake-up leaves ethanolic extract was performed to determine the compounds of alkaloids, flavonoids, glycosides, anthraquinone, saponins, tannins, steroids, and triterpenoids.

\section{Antioxidant activity test}

Quercetin solution prepared by gradual dilution to obtain solution with concentration of $1.25 \mu \mathrm{g} / \mathrm{mL}, 2.50 \mu \mathrm{g} / \mathrm{mL}, 5.00 \mu \mathrm{g} / \mathrm{mL}$, and $10.00 \mu \mathrm{g} / \mathrm{mL}$. 
Bangun-bangun leaves ethanolic extract solution prepared by gradual dilution to obtain solution with concentration of $12.5 \mu \mathrm{g} / \mathrm{mL}, 25.0$ $\mu \mathrm{g} / \mathrm{mL}, 50.0 \mu \mathrm{g} / \mathrm{mL}$, and $100.0 \mu \mathrm{g} / \mathrm{mL} .2 \mathrm{~mL}$ of solution with each concentration, added $2 \mathrm{~mL}$ of 2-2-2-azino-bis(3-ethylbenzothazoline6-sulfonic acid) solution with concentration of $7 \mathrm{mM}$, and measured the absorbance by spectrophotometer on maximum wavelength $729 \mathrm{~nm}$.

\section{Cardioprotective activity test}

The experimental animals were grouped into seven groups, each consisting of five female rats with treatment on the $1^{\text {st }-9^{\text {th }}}$ day, at the $10^{\text {th }}$ day, all experimental animals fasted $12 \mathrm{~h}$, anesthetized with ketamine $70 \mathrm{mg} / \mathrm{kg}$ bw intraperitoneally, sacrificed, taken blood samples from the hearts for the measurements of cTnT and CK-MB, the organ is taken for histology [5-8]. The experimental animal treatment is shown in Table 1. Measurement of cTnT: $1.0 \mathrm{~mL}$ of blood from rat heart is inserted into Vacutainer tube containing heparin anticoagulant, shaken until homogeneous with heparin, pipetted $150 \mu \mathrm{L}$, inserted into the sample cup, and measured cTnT levels. Measurement of CK-MB: $0.5 \mathrm{~mL}$ of blood from rat heart inserted into Vacutainer tube without heparin anticoagulant, allowed to room temperature, centrifuged at $3500 \mathrm{rpm}$ for $15 \mathrm{~min}$, pipetted $200 \mu \mathrm{L}$, inserted into sample cup, and measured CK-MB.

Histologic examination of mouse organ was examine by histologic preparations of heart organ with hematoxylin eosin reagent. Mouse heart organ taken, soaked with formalin buffer, trimmed with thickness $\pm 0.5 \mathrm{~cm}$, dehydrated with alcohol, washed with xylene, soaked in xylene and paraffin mixture, rehydrated with stratified alcohol, immersed in hematoxylin solution, dipped into in xylene, spilled with Entellan, and observed using a light microscope [9].

\section{Data analysis}

Data of research result determined homogeneity and normality to determine statistical analysis used. Data were analyzed using one-way ANOVA test to determine the mean difference between treatments using SPPS 19.0 program. If there is a significant difference, further proceed with the Tukey test to determine the differences value between treatment groups. Based on the significance value, $p<0.05$ is considered statistically significant.

\section{RESULTS AND DISCUSSION}

\section{Plant identification}

The results of plant identification at the Center for Biological Research, Indonesian Institute of Sciences (Bogor) indicate that bangun-bangun plant has family Lamiaceae and species Plectranthus amboinicus Lour.

\section{Phytochemical screening}

Phytochemical screening is performed on bangun-bangun leaves to obtain the information of classes of secondary metabolite compounds contained in the plant. The results of phytochemical screening of the bangun-bangun leaves ethanolic extract were show that alkaloids (-), flavonoids $(+)$, glycosides $(+)$, saponins $(+)$, tannins $(-)$, triterpenoids $(+)$, and steroids ( + ). The antioxidant activity is resulted by flavonoid and saponin compounds. The antioxidant activity depends on the functional group in the compound structure: Hydroxyl group or hydrogen donor group (-NH or -SH) will increase antioxidant activity [10].

\section{Antioxidant activity of bangun-bangun leaves ethanolic extract} Absorbance and scavenging percentage of bangun-bangun leaves ethanolic extract and quercetin (as the positive control) to 2,2'-azinobis(3-ethylbenzothiazoline-6-sulfonic acid) (as the free radical) can be seen in Table 2.

Regression line equation was calculated from the concentration as the absciss $(\mathrm{X})$ and scavenging percentage as the ordinate $(\mathrm{Y})$. The regression line equation obtained was $\mathrm{Y}=0.6221 \mathrm{X}+11.6274$. The inhibitory concentration $\left(\mathrm{IC}_{50}\right)$ value was calculated from the regression line equation by substituted the scavenging activity as the ordinate $(\mathrm{Y})$ with 50. The $\mathrm{IC}_{50}$ value obtained for waking up leaves ethanolic extract was $57.79 \mu \mathrm{g} / \mathrm{mL}$. The IC v $_{50}$ value obtained for quercetin was $11.33 \mu \mathrm{g} / \mathrm{mL}$.

Antioxidant activity of bangun-bangun leaves ethanolic extract is categorized as strong antioxidant, while the antioxidant activity of quercetin is categorized as very strong antioxidant. $\mathrm{IC}_{50}<50 \mu \mathrm{g} / \mathrm{mL}$ was a very strong antioxidant, $\mathrm{IC}_{50}$ between $50 \mu \mathrm{g} / \mathrm{mL}$ and $100 \mu \mathrm{g} / \mathrm{mL}$ was a strong antioxidant, $\mathrm{IC}_{50}$ between $100 \mu \mathrm{g} / \mathrm{mL}$ and $150 \mu \mathrm{g} / \mathrm{mL}$ was a moderate antioxidant, and IC $\mathrm{I}_{50}$ between $151 \mu \mathrm{g} / \mathrm{mL}$ and $200 \mu \mathrm{g} / \mathrm{mL}$ was a weak antioxidant. Quercetin has stronger antioxidant activity, due to bangun-bangun leaves ethanolic extract is not a pure compound and may still contain other compounds that have no antioxidant activity. The antioxidant activity of bangun-bangun leaves ethanolic extract was caused by phenolic compounds and polyphenolic compounds (flavonoids and saponins) in the extract [11].

Cardioprotective activity of bangun-bangun leaves ethanolic extract The cTnT value and the CK-MB value of waking up leaves ethanolic extract and quercetin (as the positive control) in doxorubicin-induced rat can be seen in Table 3 .

Animals were treated with the various doses of waking up leaves ethanolic extract and quercetin from the $1^{\text {st }}$ day to the $9^{\text {th }}$ day and

Table 1: The experimental animal treatment

\begin{tabular}{|c|c|c|c|c|}
\hline No. & Group & Description & Treatment ( $1^{\text {st }}-9^{\text {th }}$ day $)$ & Doxorubicin induced ( $8^{\text {th }}$ day and $9^{\text {th }}$ day) \\
\hline 1. & I & Normal Control & $x$ & $x$ \\
\hline 2. & II & Blank Control & Carboxymethyl Cellulose Sodium 1\% & $\checkmark$ \\
\hline 3. & III & Negative Control & $\times$ & $\checkmark$ \\
\hline 4. & IV & Positive Control & Quercetin $10 \mathrm{mg} / \mathrm{kg}$ bw & $\checkmark$ \\
\hline 5. & $\mathrm{~V}$ & Extract 1 & Extract $75 \mathrm{mg} / \mathrm{kg}$ bw & $\checkmark$ \\
\hline 6. & VI & Extract 2 & Extract $150 \mathrm{mg} / \mathrm{kg}$ bw & $\checkmark$ \\
\hline 7. & VII & Extract 3 & Extract $300 \mathrm{mg} / \mathrm{kg} \mathrm{bw}$ & $\checkmark$ \\
\hline
\end{tabular}

Table 2: Absorbance and scavenging percentage of bangun-bangun leaves ethanolic extract and quercetin to 2,2'-azino-bis (3-ethylbenzothiazoline-6-sulfonic acid)

\begin{tabular}{|c|c|c|c|c|c|c|}
\hline No & $\begin{array}{l}\text { Extract } \\
\text { concentration }(\mathrm{X})\end{array}$ & $\begin{array}{l}\text { Extract } \\
\text { absorbance }(\lambda=729 \mathrm{~nm})\end{array}$ & $\begin{array}{l}\text { Extract scavenging } \\
\text { percentage }(Y)(\%)\end{array}$ & $\begin{array}{l}\text { Quercetin } \\
\text { concentration }(\mathrm{X})\end{array}$ & $\begin{array}{l}\text { Quercetin } \\
\text { absorbance } \\
(\lambda=729 \mathrm{~nm})\end{array}$ & $\begin{array}{l}\text { Quercetin } \\
\text { scavenging } \\
\text { percentage }(Y)(\%)\end{array}$ \\
\hline 1 & Blank & 0.5456 & 0.00 & Blank & 0.4760 & 0.00 \\
\hline 2 & $12,5 \mu \mathrm{g} / \mathrm{mL}$ & 0.4336 & 20.35 & $1.25 \mu \mathrm{g} / \mathrm{mL}$ & 0.4118 & 12.53 \\
\hline 3 & $25.0 \mu \mathrm{g} / \mathrm{mL}$ & 0.3353 & 38.54 & $2.50 \mu \mathrm{g} / \mathrm{mL}$ & 0.3903 & 17.85 \\
\hline 4 & $50.0 \mu \mathrm{g} / \mathrm{mL}$ & 0.2856 & 47.64 & $5.00 \mu \mathrm{g} / \mathrm{mL}$ & 0.3376 & 29.07 \\
\hline 5 & $100.0 \mu \mathrm{g} / \mathrm{mL}$ & 0.1400 & 68.53 & $10.00 \mu \mathrm{g} / \mathrm{mL}$ & 0.2762 & 41.96 \\
\hline
\end{tabular}


followed by doxorubicin at the $8^{\text {th }}$ day and the $9^{\text {th }}$ day. The levels of endogenous antioxidants in the heart are so small that the myocardium is a highly sensitive organ to the damage caused by free radicals caused by doxorubicin. Doxorubicin with dose $20 \mathrm{mg} / \mathrm{kg}$ bw can already cause cardiotoxicity.

The cTnT level and the CK-MB level in doxorubicin group were the highest and different with other treatments. Doxorubicin forms free radicals, thereby increasing oxidative stress (anion peroxide and hydrogen peroxide) which causes cardiotoxic by forming ROS that exceeds the detoxification of cardiomyocytes. The cardiomyocyte structure, in which $50 \%$ of the organelles are mitochondria, becomes the target of doxorubicin [12].

The cTnT level and the CK-MB level in normal group were not found different with quercetin group with dose $10 \mathrm{mg} / \mathrm{kg}$ bw and wakeup leaves ethanolic extract group with dose $300 \mathrm{mg} / \mathrm{kg}$ bw. Bangunbangun of leaves of ethanolic extract has cardioprotective activity that may be produced by flavonoids contained in the bangun-bangun leaves ethanolic extract. P. amboinicus Lour. contains flavonoid in the form of quercetin (very strong antioxidant) and protects cardiomyocytes. The flavonoid protector effect is strongly associated with antioxidant activity, preventing iron chelate [13] and carbonyl reductase-1 inhibitor [14]. Flavonoids are able to protect intracellular calcium depletion and inhibit apoptosis of cardiac myocytes [15]. Heart tissue histology of bangun-bangun leaves ethanolic extract and quercetin in doxorubicin-induced rat can be seen in Fig. 1

Table 3: The cTnT value and the CK-MB value of waking up leaves ethanolic extract and quercetin in doxorubicin-induced rat

\begin{tabular}{lll}
\hline Treatment & cTnT & CK-MB \\
\hline Normal & $155.60 \pm 4.03$ & $228.08 \pm 6.53$ \\
Doxorubicin & $3651.20 \pm 7.66$ & $3158.78 \pm 43.90$ \\
Extract $75 \mathrm{mg} / \mathrm{kg} \mathrm{bw}$ & $1981.60 \pm 32.30$ & $2397.52 \pm 6.25$ \\
Extract $150 \mathrm{mg} / \mathrm{kg} \mathrm{bw}$ & $1324.20 \pm 34.99$ & $1504.28 \pm 29.92$ \\
Extract $300 \mathrm{mg} / \mathrm{kg} \mathrm{bw}$ & $670.40 \pm 41.37$ & $787.70 \pm 34.66$ \\
Quercetin $10 \mathrm{mg} / \mathrm{kg} \mathrm{bw}$ & $673.40 \pm 41.59$ & $851.12 \pm 27.68$ \\
Carboxymethyl cellulose & $3298.80 \pm 10.47$ & $3095.86 \pm 3.74$ \\
sodium $1 \%$ & & \\
\hline
\end{tabular}

cTnT: Cardiac troponin T, CK-MB: Creatine kinase-muscle/brain
Normal muscle tissue structure belongs to the normal group, wake group, leaves ethanolic extract group with dose $300 \mathrm{mg} / \mathrm{kg}$ bw, and quercetin group with dose $10 \mathrm{mg} / \mathrm{kg}$ bw which means that no myocardial damage occurs. The results of cardiac histology examination in the doxorubicin group occurred bleeding, damage to some cell nuclei, i.e., pyknosis (characterized by shrunken cell nuclei and dark color) and progressed to chronic conditions, i.e., karyolysis (characterized by very pale and colorless cell nuclei), cell nuclei have loss of shape, fragmentation and damage of heart muscle fibers (myocytolysis).

Reactive oxygen species can affect proteins and nucleic acids, particularly ion channels and ion transporters. Oxidative stress also affects homeostasis $\mathrm{Ca}^{2+}$ directly through mitochondrial transfusion induction of mitochondrial transition with changes in calcium transport in the mitochondria. Changes in calcium transport can cause tissue damage, cell death, and heart contraction disorders. Endogenous antioxidant enzymes such as glutathione peroxidase, catalase, and superoxide dismutase have the ability to deactivate free radicals [16].

Flavonoids can increase the activation of endogenous antioxidants and reduce free radicals. Flavonoids inhibit the enzymes responsible for producing superoxides such as xanthine oxidase. Flavonoids can inhibit cyclooxygenase and lipoxygenase, thus reducing the production of free radicals $[13,17-19]$.

\section{CONCLUSION}

Ethanolic extract of waking leaves $\mathrm{IC}_{50}$ value of $57.79 \mu \mathrm{g} / \mathrm{ml}$ and has strong antioxidant activity. Ethanolic extract of wakeup leaves has a cardioprotective activity to lowering the CK-MB value and lowering the damage of mouse heart tissue induced by doxorubicin based on the histologic of cardiac tissue.

\section{AUTHOR'S CONTRIBUTION}

All the authors have the same contribution in this research (carried out the research, collected the data, analyzed the data, and formatted the manuscript).

\section{CONFLICTS OF INTEREST}

The authors declare that they have no conflicts of interests in this research and this article.
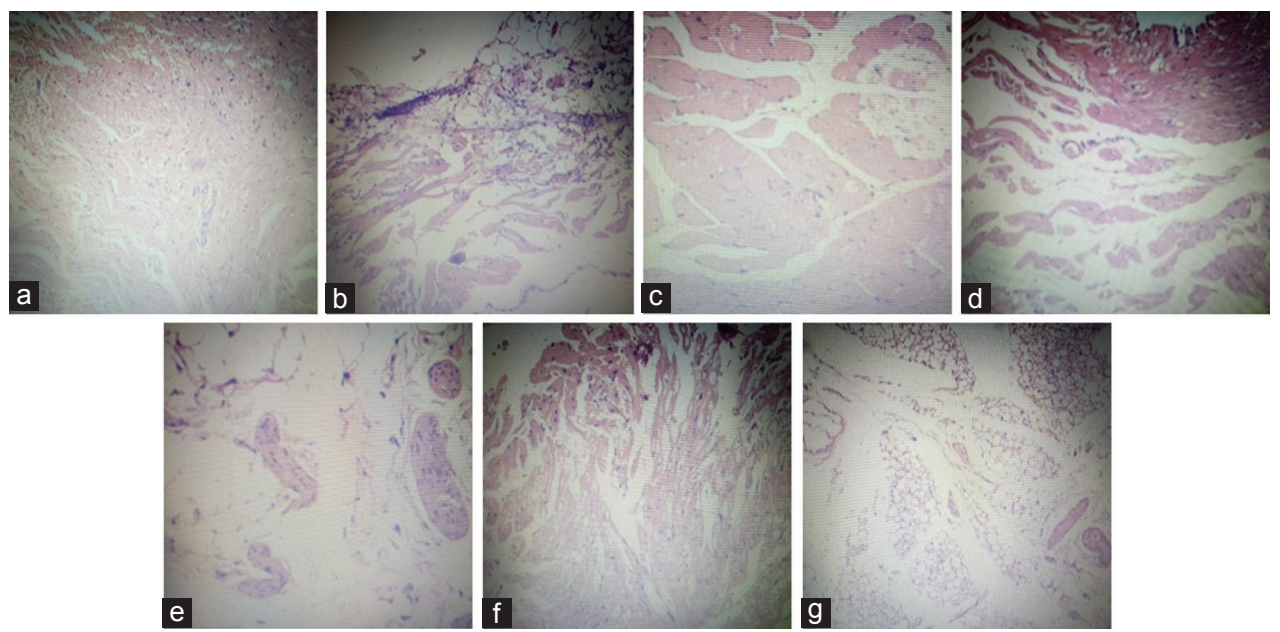

Fig. 1: (a) Normal, (b) doxorubicin, (c) quercetin $10 \mathrm{mg} / \mathrm{kg}$ bw, (d) extract $75 \mathrm{mg} / \mathrm{kg} \mathrm{bw}$, (e) extract $150 \mathrm{mg} / \mathrm{kg} \mathrm{bw}$, (f) extract $300 \mathrm{mg} / \mathrm{kg}$ bw, (g) carboxymethyl cellulose sodium $1 \%$ 


\section{REFERENCES}

1. Arafa HM, Abdellah MF, Hafez HF. Abatement by naringenin of doxorubicin induced cardiac toxicity in rats. J Egypt Natl Cancer Inst 2005;14:230-91.

2. Hariana AH. Herbal Medicine and the Activity. Jakarta: Penebar Swadaya; 2005.

3. Lukhoba CW, Simmonds MSJ, Paton AJ. Plectranthus-a review of ethnobotanical uses. J Ethnopharmacol 2006;103:1-24.

4. Ministry of Health (Republic of Indoesia). Indonesia Pharmacopoeia. $3^{\text {rd }}$ ed. Jakarta: Department of Health (Republic of Indonesia); 1979.

5. Chennuru A, Saleem MT. Antioxidant, lipid lowering, and membrane stabilization effect of sesamol against doxorubicininducedcardiomyopathy in experimental rats.BioMed Res Int 2013. DOI: org/10.1155/2013/934239:1-5.

6. El-Sayed E, Abd Elazeem A, Afify A, Shabana M, Ahmed H. Cardioprotective effects of Curcuma longa L. extracts against doxorubicininduced cardiotoxicity in rats. J Med Plant Res 2011;5:4050.

7. Adamcova M, Sterba M, Simunek T, Potacova A, Popelova O, Mazurova Y. Troponin as marker of myocardiac damage in druginduced cardiotoxicity. Expert Opin Drug Saf 2005;4:457-65.

8. Abdel-Raheem I,Taye A, Abouzied M. Cardioprotective effects of nicorandil, a mitochondrial potassium channel opener against doxorubicin induced cardiotoxicity in rats. Basic Clini Pharmacol Toxicol 2013;113:159.

9. Sudiana I. Teknologi Ilmu Jaringan dan Imunohistokimia. Jakarta: Sagung Seto; 2005.

10. Amic D, Davidovic-Amic D, Beslo D, Trinajstic N. Structureradical scavenging activity relationships of flavonoids. Croat Chem Acta
2002;76:55

11. Krishnamurthy P, Wadhwani A. Antioxidant enzymes and human health. Intech 2012;1:3-9.

12. Gewirtz D. Critical evaluation of the mechanisms of action proposed for the antitumor effects of the anthracycline antibiotics adriamycin and daunorubicin. Biochem Pharmacol 1999;57:727.

13. Kaiserová H, Simunek T, van der Vijgh WJ, Bast A, Kvasnicková E. Flavonoids as protectors against doxorubicin cardiotoxicity-role of iron chelation, antioxidant activity and inhibition of carbonyl reductase. Biochim Biophys Acta 2007;1772:1065-74

14. Carlquist M, Frejd T, Gorwa-Grauslund MF. Flavonoids as inhibitors of human carbonyl reductase 1. Chem Biol Interact 2008;174:98-108.

15. Zheng J, LeeHC, Bin-Sattar MM, Huang Y. Cardioprotective effects of epigallocatechin-3-gallate against doxorubicininduced cardiomyocyte injury. Eur J Pharmacol 2011;652:82-8.

16. Schimmel KL, Richel DJ, van den Brink RB, Guchelaar HJ. Cardiotoxicity of cytotoxic drugs. Cancer Treat Rev 2004;30:181-91.

17. Ragavendran P, Sophia D, Arulraj C, Gopalakrishnan VK. Cardioprotective effect of aqueous, ethanol, and aqueous ethanol extract of Aerva lanata (Linn.) against doxorubicin induced cardiomyophaty in rats. Asian Pac J Trop Biomed 2012;2:212-18.

18. Varadharajan R, Rajalingam D, Palanic S. Mass chromatography mas sepctrometry/mas spectrometry analysis and cardioprotective potential of Cucumis callosus on doxorubicin induced cardiotoxicity in rats. Int J Pharm Pharm Sci 2016;8:239-45.

19. Ravichandra V, Hanumantharayappa B, Madhava RP. Evaluation of cardioprotective activity of galangin against doxorubicin induced cardiomyopathy. Int J Pharm Pharm Sci 2014;6:86-90. 